\title{
Remunerations and Burnout in Mexico
}

\author{
Rosalba Treviño Reyes \\ Autonomous University of Nuevo Leon
}

\author{
Adriana Segovia Romo \\ Autonomous University of Nuevo Leon
}

\author{
Elías Alvarado Lagunas \\ Autonomous University of Nuevo Leon
}

With the current pace of working life and the demands of a globalized world, more and more people are suffering from burnout syndrome. This has led Mexico to occupy first place worldwide in work stress. This research analyzes remunerations, psychological empowerment, and burnout in teachers of public institutions of middle higher education. Using a model of structural equations, it was observed that the results do not support the inverse relationship between compensation with burnout through psychological empowerment, hence the hypothesis was rejected.

\section{INTRODUCTION}

With the constant and reeling changes experienced by the globalized world, the study of human capital in the organizational plane has grown in importance. In recent years, there has been a growing interest in studying various factors of organizational behavior in order to facilitate the understanding of the interpersonal relationships in which people interact. This allows the organization to make decisions that lead to greater efficiency on the part of its employees.

It has never been so important for managers to understand organizational behavior as it is today. In 2015, a survey of 7,700 millennials from 29 countries in emerging and developed markets around the world showed that many of them express feelings of wanting to leave their organization by 2020 (Deloitte, 2016). If there are no changes in the way of retaining and training talent, companies in Mexico will face problems in the inclusion and retention of the millennial generation. Companies can also suffer the scarcity of competitive profiles, a problem that currently affects 4 out of 10 organizations in the country (Cadavid, 2015, cited in CNNExpansión, 2016). Deloitte (2017) noted in its fifth global survey on millennials that $66 \%$ prefer flexible work schemes to increase commitment, health, happiness, and achieve the objectives of the organization.

Another problem identified by Nava (2016, cited in El Universal, 2016) is that people who work up to 11 hours a day are more likely to suffer depression and suffer from a heart attack. In Mexico, employees work an average of 2,246 hours a year, the most in the world. In addition, people retire at age 73 while the average life span in Mexico is 75. In a study conducted by the National Autonomous University of 
Mexico (UNAM) on more than 500 professionals, 100\% presented some degree of stress, while $60 \%$ obtained high rates of it in addition to physical damage (Periódico Correo, 2016).

Occupational health authorities point out that most world laws stipulate that a person should work 40 hours a week at most. However, people in Mexico work for an estimated 48 hours per week (without counting overtime). This has consequences physically and psychologically. It may also cause deterioration in family relationships (La Unión, 2016). The Organization for Economic Cooperation and Development (OECD) indicates that Mexico occupies the first place worldwide in work stress, with excessive work days, in addition to fewer vacation days per year than other countries (Periódico Correo, 2016).

The occurrence of burnout amongst employees has been of great interest to many for almost four decades, especially to human services professionals. Burnout is defined by Maslach (2003) as the chronic stress response formed by three fundamental factors: emotional exhaustion, depersonalization, and low personal fulfillment.

Other factors that have a great impact on the labor force are remuneration and empowerment. In general, employees want compensation or compensation systems that they perceive as fair and proportional to their skills and expectations. Payment is an important consideration in the administration of human resources because it offers employees a tangible reward for their services. It is also a source of recognition and sustenance (Villanueva and González, 2005).

In addition, Molina (2006) points out that the term empowerment means enabling, granting, and allowing a person to act by themselves and encourage initiative in others. Empowerment is synonymous with a culture of participation that requires the participation of all to achieve quality objectives. This term is made up of two variants: group and individual.

According to contextual background and related empirical research, it is argued that remuneration and psychological empowerment in organizations could have an inverse impact against burnout. Although there are studies in lucrative companies and care services, there is still an epistemological vacuum in the field of teaching.

\section{Research Question}

What is the impact of compensation on burnout through psychological empowerment in teachers of public institutions of middle higher education?

\section{General objective}

To determine the impact of remuneration on burnout through psychological empowerment in teachers of public institutions of middle higher education in the citrus region of the state of Nuevo León, in Mexico.

\section{Hypothesis}

H1: Remuneration inversely impacts burnout through psychological empowerment in teachers of public institutions of middle higher education.

\section{THEORETICAL FRAMEWORK}

For almost four decades, burnout has been a topic of interest, especially amongst human services professions. Moriana and Herruzo (2004) explain that in the 1970s the concept of burnout appears in the early works of Freudenberger (1975). Although before the end of that decade, there were already many references on this subject in various care professions, including that of teachers (Keavney and Sinclair, 1978; Kyriacou and Sutcliffe, 1977). But it was not until the 1980s that research on burnout grew significantly.

O'Brien (2010) points out that burnout is a problem that can have negative consequences for organizations. The Burnout Theory of Maslach (2003) is the most often used to explain burnout in the 
nursing profession and in other human services. Therefore, for this study, burnout is defined as a chronic stress response formed by three fundamental factors: emotional exhaustion, depersonalization and low personal fulfillment.

On the other hand, remuneration, in economic terms, is defined as the payment that an employee receives for his labor (Rubio and Piatti, 2000). Diomede (2008) explains that compensation is a key system for organizations so long as it is based on equity. For Villanueva and González (2005), these include base remuneration, incentives and benefits. For some authors, remuneration is the most important motivator for the workforce to feel satisfied and motivated, which can be related to psychological empowerment. Westerman, Beekun, Daily and Vanka (2009) identified the organizations' search for new forms of compensation that allow them to adapt to the current world. Martín, N., Hernangómez and Martín, V. (2007) recommend that the compensations be equal to the contributions employees make; so that there is enough income to compensate all those involved. Through this, satisfaction is achieved, making the organization reach a state of equilibrium. On the other hand, Segovia (2014) found a nonsignificant relationship $(\mathrm{b}=.197 ; \mathrm{p}=\mathrm{ns})$ between variable compensation and psychological empowerment.

As it is observed, there is little or no existence of articles that specifically relate the variable of remuneration with psychological empowerment in an exact or direct way, and even with burnout, considering that an exhaustive search was carried out in various databases such as: GoogleScholar, ProQuest, Emerald, ResearchGate and Ebsco Host.

The concept of psychological empowerment is described by Thomas and Velthouse (1990) and Spreitzer (1995) as the increase of intrinsic motivation in the performance of the function. It stems from four concepts: meaning of the task, competence, self-determination and impact. These orient the focus of the individual towards the performance of their function, emphasizing that psychological empowerment is not a characteristic of the personality, but it is a set of cognitions defined based on a certain work context. Several studies have linked psychological empowerment with burnout (Sprietzer, 1995; Fuller, Morrison, Jones, Bridger and Brown, 1999; Hochwalder and Brucefors, 2005; Hechanova, Alampay and Franco, 2006; Hockwalder, 2007).

Theorists maintain that if workers have psychological empowerment, they feel competent in the execution of the work. Perceiving that the work makes sense impacts the achievement of the organization's objectives, and having control over their work, they experience less stress in the work that leads to burnout (Sprietzer, 1995; Thomas and Velthouse, 1990). Laschinger, Finegan, Shamian and Wilk (2004) used a longitudinal design to study the structural and psychological empowerment in burnout in 192 nursing professionals. The results obtained illustrate that psychological empowerment had a negative effect on emotional exhaustion three years later $(B=-.28)$, that is, the reverse effect of psychological empowerment on burnout can persist over time. O'Brien (2010) found that psychological empowerment was significantly and inversely related to burnout $(\mathrm{r}=0.349, \mathrm{p}=0.000)$, in her research in nurses working with patients in hemodialysis centers, using said variable as a mediator.

\section{METHOD}

The methodological design used was non-experimental and the type of research is correlational/ causal, with a mixed approach. Since a qualitative study was translated into a quantitative one where bibliographic research was used for the development of the theoretical framework, the field research was done through administering questionnaires to obtain information relevant to the study. A valid and reliable measurement instrument was developed from scales already validated in previous studies: the surveys that measure the effectiveness of remunerations in the employee in the studies of Madero (2012; 2010), The Psychological Empowerment Scale (Spreitzer, 1995, cited in O'Brien, 2010) and The Maslach Burnout Inventory (Maslach and Jackson, 1981), previously translated and validated by experts.

A population of 296 teachers from public institutions of middle higher education in the citrus region of the state of Nuevo León, Mexico, was considered. According to the calculation of the sample size (Gabaldon, 1980), a sample size "n" of 167 elements was obtained. Finally, a model of structural 
equations (Structural Equation Modeling, SEM) was used by the SmartPLS 3.0 M3 (Hair, Hult, Ringle and Sarstedt, 2017) as a statistical tool for the analysis of results.

\section{RESULTS}

Based on the application of the measurement instrument to 167 teachers with the characteristics of the selected population, the results presented considered the responses of the items on the Likert scale, verified the reliability of the instrument by Cronbach's alpha and fulfilled that criterion in each of the variables.

The results of the composite reliability index surpass the value of 0.80 in all the variables of this investigation (table 1); and although some of them are greater than 0.90 , they do not exceed the 0.95 mark to be considered as definitely undesirable. This index is considered a better approximation than Cronbach's alpha, since it assumes that the parameters are accurate and applies only when the latent variable has reflexive indicators.

TABLE 1

RESULTS OF THE MEASUREMENT ANALYSIS OF THE ÍTEMS MODEL: RELIABILITY

\begin{tabular}{lccc}
\hline Variable & Cronbach's Alpha & Composite reliability & $\begin{array}{c}\text { Average variance } \\
\text { extracted (AVE) }\end{array}$ \\
\hline Remunerations & 0.936 & 0.950 & 0.759 \\
Psychological empowerment & 0.913 & 0.931 & 0.660 \\
Burnout & 0.803 & 0.872 & 0.630 \\
\hline
\end{tabular}

Source: Prepared by the authors

According to Hair et al. (2017) the AVE (average variance extracted) is an indicator of reliability. A value of 0.50 or greater indicates a sufficient degree of convergent validity, which means that, on average, the latent variable explains more than half of the variance of its indicators. Analyzing table 1, all variables exceed the value of 0.50 .

The structural model (inner model) specifies the relationships between the unobserved or latent variables. The trajectories or betas of the relations and the value of the $\mathrm{R}^{2}$ are estimated; the latter representing the degree of explanation of the independent variables on the dependent variable. The closer to value of $R^{2}$ is to 1 , the greater the variance explained by the model. The values of $R^{2} 0.668$ and 0.178 in Table 2 are within the parameters considered acceptable.

TABLE 2

\section{RESULTS OF $\mathbf{R}^{2}$}

\begin{tabular}{lll}
\hline Variable & $\mathrm{R}^{2}$ & Adjusted R \\
\hline Psychological Empowerment & 0.668 & 0.664 \\
Burnout & 0.178 & 0.163 \\
\hline
\end{tabular}

Source: Prepared by the authors

Nonparametric bootstrapping analysis involving repeated random samples is applied. Table 3 shows the results obtained in the structural model, observing the standardized beta values $t$ - student and the significance of the hypothesis's relationships with its direct and indirect effects, the latter being where the effect is valued. mediator of the psychological empowerment variable. 
TABLE 3

ANALYSIS OF SIGNIFICANCE OF DIRECT AND INDIRECT EFFECTS

\begin{tabular}{ccccccccc}
\hline $\begin{array}{c}\text { Relationship } \\
\text { between } \\
\text { variables }\end{array}$ & $\begin{array}{c}\text { Direct } \\
\text { effect }\end{array}$ & $\begin{array}{c}t \text { of } \\
\text { studen } \\
\mathrm{t}\end{array}$ & $\begin{array}{c}p \text { value } \\
(\text { sig. })\end{array}$ & $\begin{array}{c}\text { Significance } \\
(\mathrm{p}<0.05)\end{array}$ & $\begin{array}{c}\text { Indirect } \\
\text { effect } \\
(\text { With } \\
\mathrm{PE})\end{array}$ & $\begin{array}{c}\boldsymbol{t} \text { of } \\
\text { studen } \\
\mathrm{t}\end{array}$ & $\begin{array}{c}p \text { value } \\
(\mathrm{sig})\end{array}$ & $\begin{array}{c}\text { Significance } \\
(\mathrm{p}<0.05)\end{array}$ \\
\hline $\mathrm{REM} \rightarrow$ BUOT & -0.136 & 1.320 & 0.187 & No & 0.004 & 0.150 & 0.881 & No \\
\hline
\end{tabular}

Note: REM, remunerations; PE, psychological empowerment; BOUT, burnout.

Source: Prepared by the authors

The results shown in Table 4 reflect that the relationship has a non-significant indirect effect, evaluated according to Hair et al. (2017) as a "no mediation without effect"; therefore, the proposed research hypothesis is rejected.

TABLE 4

CHECKING THE INVESTIGATION HYPOTHESIS

\begin{tabular}{lllll}
\hline Specific hypotheses & & Effect & $\begin{array}{l}\text { Checking } \\
\text { hypothesis }\end{array}$ \\
\hline $\begin{array}{l}\text { H1. Remuneration impacts inversely on burnout through } \\
\text { psychological empowerment }\end{array}$ & $\begin{array}{l}\text { No mediation without } \\
\text { effect }\end{array}$ & Rejected \\
\hline
\end{tabular}

Source: Prepared by the authors

\section{CONCLUSIONS}

The general objective of the research was to determine the impact of remuneration on burnout considering the psychological empowerment in its mediating role. According to the interpretation of results, the research hypothesis (H1) is rejected since the results do not support the inverse relationship between compensation with burnout through psychological empowerment. Although no theory or empirical research was found in the antecedents that studied such variables, this serves as a contribution to the existing epistemological vacuum in this field of science and in the population segment studied in this research. Findings shows similarity with what was researched by Segovia (2014) who when studying the variable of compensation with psychological empowerment, rejected his hypothesis to find a nonsignificant relationship.

In addition, a non-existent relationship was found within the direct effects between remuneration and burnout in the present work, which means that while teachers may receive high remuneration from educational institutions, they do not influence a decrease in burnout levels. Even considering the mediating role of psychological empowerment, the relationship remains non-significant. This implies the search for other factors of organizational well-being that lead to a reduction in the stress of the teachers, when facing the educational and labor needs. These findings are in contrast to the theoretical premises and results of the investigations in hospital nurses that were analyzed in the literature review (Sprietzer, 1995; Fuller, Morrison, Jones, Bridger and Brown, 1999; Hochwalder and Brucefors, 2005; Hechanova, Alampay and Franco, 2006; Hockwalder, 2007).

Significant contributions are made to the epistemological vacuum in the Mexican context addressed to teachers on the variables analyzed in the country, the population, and area selected to investigate (Creswell, 2015), which is a geographical area with significant economic, organizational, commercial, educational, and cultural development in recent decades, outside the metropolitan area of Monterrey, Nuevo León, Mexico, and not yet covered by the revised literature. Another contribution is the 
investigation of the proposed model in a different context, such as higher education institutions in Mexico, a field that has not been studied empirically (Barraza, 2008).

This research allows educational institutions to design strategies that may affect intrinsic remuneration and motivation such as psychological empowerment. Such strategies may help in assuring that teachers feel supported in multiple aspects, hence causing a reduction of their stress levels and avoiding burnout. Teaching can be considered as one of the professions with greater workload inside and outside the classroom, hence it is essential that the well-being of teachers is supported by their institutions.

In the same way, this research work has applications not only for the institutions which were subjects of the study but also for the institutions of other entities of the country, dependencies of other levels of the educational system and, finally, for organizations of any other field that are interested in understanding the factors that significantly affect the level of burnout amongst employees with the end goal of addressing it.

\section{REFERENCES}

Barraza, A. (2008). Compromiso organizacional docente. Un estudio exploratorio. Avances en Supervisión Educativa, 8, Asociación de Inspectores de Educación en España.

CNNExansión. (2016). 5 beneficios de negocio que trae el "engagement" laboral. La competitividad de las empresas se eleva cuando sus colaboradores se comprometen emocionalmente con la organización. Retrieved from http://expansion.mx/carrera/2016/08/10/5-beneficios-de-negocioque-trae-el-engagement-laboral

Creswell, J. W. (2015). Research Design: Qualitative, quantitative, and mixed method approaches. 4th. Edition. Thousand Oaks: Sage Publications.

Deloitte (2016). Encuesta Millennials 2016 Conquistando a la siguiente generación de líderes. Retrieved from https://www2.deloitte.com/mx/es/pages/about-deloitte/articles/millenial2016.html

Deloitte (2017). Encuesta Millennials 2017. ¿Qué mundo quieren habitar? Retrieved from https://www2.deloitte.com/mx/es/pages/about-deloitte/articles/encuesta-millennial-2017.html

Diomede, H. (2008). Compensaciones se escribe con " $E$ " de equidad. Retrieved from http://pt.slideshare.net/Diomede07/compensaciones-se-escribe-con-e-de-equidad

El Universal (2016). Mexicanos, más expuestos a enfermedades por largos horarios laborales. Retrieved from http://www.eluniversal.com.mx/articulo/ciencia-y-salud/salud/2016/10/31/mexicanos-masexpuestos-enfermedades-por-largos-horarios

Freudenberger, H. (1975). The staff burn-out syndrome in alternative institutions. Psychotherapy, Theory, Research and Practice, 12(1), 73-82.

Fuller, J., Morrison, R., Jones, L., Bridger, D., \& Brown, V. (1999). The effects of psychological empowerment on transformational leadership and job satisfaction. The Journal of Social Psychology, 139(3), 389-391.

Gabaldon, N. (1980). Algunos conceptos de muestreo (3ra. Ed.). Caracas, Venezuela: Universidad Central de Venezuela, Facultad de Ciencias Económicas y Sociales, División de publicaciones.

Hair, J. F., Hult, G. T. M., Ringle, C. M., \& Sarstedt, M. (2017). A Primer on Partial Least Squares Structural Equation Modeling. 2nd Ed. Thousand Oaks: Sage.

Hechanova, M.R., Alampay, R.B., \& Franco, E. (2006). Psychological empowerment, job satisfaction and performance among Filipino service workers. Asian Journal of Social Psychology, 9, 72-78.

Hochwalder, J. (2007). The psychosocial work environment and burnout among Swedish registered and assistant nurses: The main, mediating and moderating role of empowerment. Nursing and Health Sciences, 9(3), 205-211.

Hochwalder, J., \& Brucefors, A. (2005). Psychological empowerment at the workplace as a predictor of ill health. Personality and Individual Differences, 39, 1237-1248.

Keavney, G., \& Sinclair, K. E. (1978). Teacher concerns and teacher anxiety: A neglected topic of classroom research. Review of Educational Research, 48(2), 273-290 
Kyriacou, C., \& Sutcliffe, J. (1977). Teacher stress: A review. Educational Review, 29(4), 299-306. La Unión (2016). México es el país con los horarios laborales más largos: UNAM. Retrieved from https://www.launion.com.mx/blogs/vida-y-estilo/noticias/97524-mexico-es-el-pais-con-loshorarios-laborales-mas-largos-unam.html

Laschinger H., Finegan J. E., Shamian J., \& Wilk P. (2004) Longitudinal analysis of the impact of workplace empowerment on work satisfaction. Journal of Organizational Behavior, 25, 527-544.

Madero, S. M. (2012). La efectividad de las compensaciones, la satisfacción del trabajador y las dimensiones del ambiente laboral. CIENCIA-UANL, 15(57), 93-100.

Madero, S. M. (2010). Factores relevantes del desarrollo profesional y de compensaciones en la carrera laboral del trabajador. Contaduría y administración, 232, 109-130.

Martín, N., Hernángomez, J., \& Martín, V. (2007). El deleite de la eficiencia. Universia Business Review, 5(14), 56-67.

Maslach, C. (2003). Job burnout new directions in research and intervention. Current directions in psychological science, 12(5), 189-192.

Maslach, C., \& Jackson, S.E. (1981). MBI: Maslach Burnout Inventory Manual. Palo Alto: University of California, Consulting Psychologists Press.

Molina, R. (2006). Empowerment ¿actitud mental?, ¿técnica?, ¿estrategia? O ¿moda? México: Trillas.

Moriana, J.A. \& Herruzo, J. (2004). Estrés y burnout en profesores. Universidad de Córdoba, España.

O'Brien, J. L. (2010). Structural empowerment, psychological empowerment and burnout in registered staff nurses working in outpatient dialysis centers (Doctoral dissertation, Rutgers UniversityGraduate School-Newark).

Periódico Correo (2016). Aumenta síndrome de burnout en personas de entre 25 y 40 años. Retrieved from http://periodicocorreo.com.mx/aumenta-sindrome-de-burnout-en-personas-de-entre-25-y40-anos/

Rubio, V., \& Piatti, G.M. (2000). Manual de remuneraciones. Argentina: Cuyo.

Segovia, A. (2014). El liderazgo, la compensación variable, el empowerment psicológico y su impacto en la efectividad del empleado: un enfoque de modelación mediante ecuaciones estructurales (Doctoral dissertation, Universidad Autónoma de Nuevo León).

Spreitzer, G. M. (1995). "Psychological Empowerment in the Workplace: Dimensions, Measurement, and Validation". The Academy of Management Journal, 38(5), 1442-1465.

Thomas, K., \& Velthouse, B. (1990). Cognitive Elements of Empowerment: An "Interpretive" Model of Intrinsic Task Motivation. Academy of Management Review, 15, 666-681. Retrieved from https://www.jstor.org/stable/258687?seq=1\#page_scan_tab_contents. DOI: 10.2307/258687

Villanueva, A., \& González, E. (2005). Gestión en las compensaciones. Chile: Paidós.

Westerman, J.W., Beekun, R.I., Daily, J., \& Vanka, S. (2009). Personality and national culture. Predictors of compensation strategy preferences in the USA and India. Management Research News, 32(8), 767-781. 